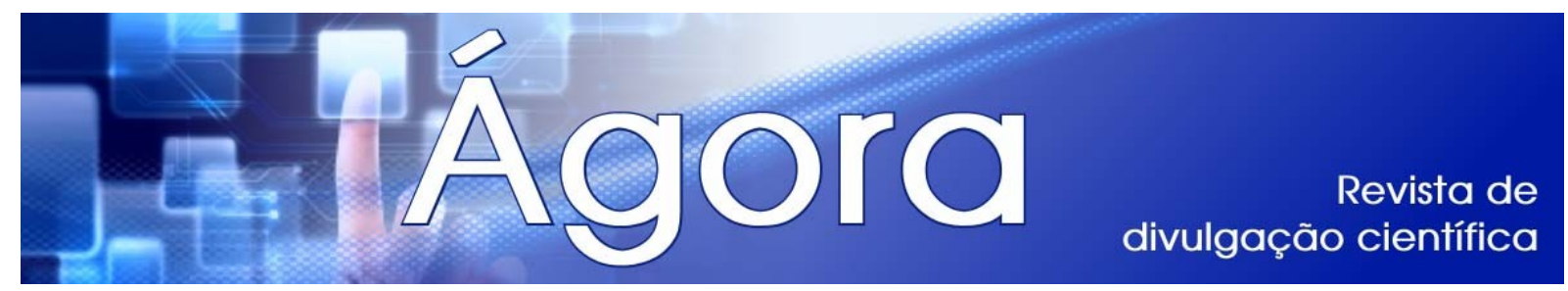

\title{
A HISTORIA DA CULPABILIZAÇÃO DO CORPO
}

Rafael Marcio Chapieski ${ }^{1}$

RESUMO: Este artigo apresenta elementos para a reflexão sobre alguns aspectos da História do Corpo e a suas implicações no cotidiano, a culpabilização e diversas formas de pensamentos relacionados à sexualidade, afetividade e à emoção, conduzindo a reflexão para a Psicomotricidade Relacional.

Palavras chave: Corpo; Psicomotricidade; Psicomotricidade relacional; Culpa.

ABSTRACT: This article shows elements about some aspects of the body's history and its implications in the everybody and divers forms of thin king related with the sexuality, affectivity and the emotion, conducting the reflection to the "Relacional Psiconotricity".

Keywords: Body; Psychomotricity; relational Psychomotricity; Guilt.

\section{INTRODUÇÃO}

Quer se trate do Corpo de outrem, quer se trate do meu, não tenho outro modo de conhecer o Corpo humano senão vivendo-o, isto é, assumindo por minha conta o drama que me atravessa e confundindo-me com ele (MERLEAU-PONTY, 1950, p.86).

O Homem sempre demonstrou muita dificuldade em ver, sentir seu próprio corpo e o corpo do outro. $\mathrm{O}$ apelo que se percebe, é sempre em querer dividir o Corpo, na tentativa de explicá-lo, colocando a Alma, ser espiritual e consciente, separada do Corpo material. Esse dualismo psicofísico percorre todo pensamento filosófico que a humanidade, ao longo de sua história, produziu e manifestando-se em todas as áreas do conhecimento, quer matemáticas, espirituais, humanas ou sociais. O Homem tem muita dificuldade de aceitar e entender, que conforme as palavras de Adélia Prado, "Sem o corpo a alma não goza".

\footnotetext{
${ }^{1}$ Graduado em Filosofia. Mestre em Ciências Sociais. Doutor em Historia. E-mail: rafaelchapieski@unc.br
}

Ágora: R. Divulg. Cient., v. 18, n. 2, p. 138-160, dez. 2011 (ISSN 2237-9010) 
Sofre-se de uma gloriosa tradição negativa em relação ao corpo humano. Parece mentira que com tanta matança coletiva nos campos de batalha, tão poucos se preocuparam em saber como era o corpo.

A anatomia de hoje começou há quinhentos anos, mais ou menos. São contadas histórias de roubo de cadáveres em cemitérios, porque cortar gente morta a fim de estudar anatomia era tido como uma espécie de sacrilégio, assim como seus desejos tidos como pecaminosos.

O homem, positivamente e desde sempre, jamais quis se conhecer corporalmente! No Oriente, a profanação de cadáveres era severamente punida, devido à reverência dos vivos em relação aos antepassados, verdadeira religião para tantos orientais.

No primeiro período áureo da arte humana, entre 50 mil e 20 mil anos atrás, os artistas desenharam animais em grande profusão e com maestria. Mas as figuras humanas são muito raras e muito esquemáticas. Os homens não se interessavam por eles mesmos. Existem projetados nas coisas.

Enquanto a humanidade era constituída por pequenos bandos de caçadores errantes, é pouco provável que alguma vez sobrassem coisas para ser de alguém. Só se possuía o que se usava, aqui e agora, ou daqui a pouco.

Um belo dia, um dos primeiros gênios da humanidade descobriu que seguir continuamente um rebanho era bem mais complicado que fazer uma cerca e segurar o rebanho dentro. E assim nascia a propriedade particular. A noção e o fato social da propriedade particular, intimamente ligado à noção de poder, cresceu e frutificou abundantemente e então nasceu na cabeça de outro ser racional, a ideia de prender outros homens dentro da cerca: os escravos. Surgiu a propriedade de serviços e não de coisas, de usar as pessoas e não de comê-las.

E assim nasceu e foi-se desenvolvendo a noção de que o corpo é um escravo da mente, portanto, uma coisa inferior com a qual se pode fazer o que se quiser. Apesar de que isto, na maioria das vezes, seja impossível. Marx foi um dos que denunciou esta relação entre o opressor e o oprimido, corpo e mente.

Ao mesmo tempo em que se inferiorizava o corpo, exaltava-se a alma, acabando por se estabelecer entre ambos a mesma distância intransponível que existe entre o senhor e o escravo. 
Algumas sociedades antigas, através da reflexão filosófica, procuraram entender e por vezes, justificar esta dicotomia entre o corpo e a mente. O povo que com mais profundidade e coerência estabeleceu estas diferenças entre o corpo e alma, foram os gregos.

Atualmente, existem muitas reflexões que buscam perscrutar o ser humano e entendê-lo como um ser único. Porém, encontra-se com bastante evidência a presença do pensamento grego. Nos processos educacionais, bem como em muitos fundamentos religiosos ou nas artes e na literatura.

O homem é grego, cristão e cartesiano, estruturalmente. Os processos científicos gravitam em busca de verdades cartesianas. As religiões cristãs de uma maneira geral têm seus discursos baseados na pureza da Alma e na imperfeição do Corpo, caído e gerador de desgraças e infortúnios.

\section{AS INTERPRETAÇOES DE UM CORPO CULPABILIZADO AO LONGO DA HISTÓRIA}

O pensamento Grego no século V a.C., com Platão desenvolve a Teoria do Conhecimento, que através da alegoria do Mito da Caverna, justifica a existência da Alma separada do Corpo. Diz que a Alma encarna, após ter contemplado o Mundo das Ideias, onde não existe multiplicidade. O conhecimento intelectual lá se dá de formas direta e imediata dispensando o uso dos sentidos. Quando se dá a encarnação da Alma no corpo, esta se degrada, tornando-se prisioneira do mesmo. Após esse fato se terão duas realidades: a Alma Superior (Intelectiva) de ouro, e os que a possuem, detêm o poder de contemplar a Verdade, o verdadeiro conhecimento. De acordo com Platão, seriam os dirigentes, Reis-Filósofos e, a Alma Inferior (corporal) divide-se ainda, em Irascível (prata), que tem sua morada no peito, é impulsiva e os que a detêm, são guerreiros, e finalmente a Concupiscível (bronze), localizada no ventre e está voltada para os desejos de bens materiais e apetite sexual.

A luta entre a Alma Superior e Inferior compõe o drama da vida humana, segundo Platão. A Inferior dificulta o verdadeiro conhecimento, escraviza através dos sentidos, leva à decadência moral. Dessa forma, faz-se necessário controlar as paixões e os desejos, para se ter um comportamento moral adequado. 
Em sua obra O Banquete, Platão diz que a admiração pela beleza física predomina durante a juventude, mas aquele que segue Eros, amadurece e percebe que a verdade está na Alma e não no Corpo.

Pode parecer paradoxal, mas os gregos que criaram as Olimpíadas, desenvolveram a ideia "Corpo são em mente sã" pois pensavam que o domínio do corpo ajudaria a fazer com que a Alma não ficasse preza aos prazeres físicos. Nos dias atuais, em muito, a doutrina platônica está presente - quando as academias, escolas de ginástica e "aulas de educação física" preocupam-se em treinar o domínio, o adestramento corporal, e não permitindo ao corpo expressar-se tal como é, VIDA.

O Cristianismo busca fundamentar sua doutrina em relação ao corpo e ao prazer, nos filósofos gregos. Platão de uma certa maneira foi batizado por Santo Agostinho de Hipona, que entendia o prazer como um companheiro perigoso e o homem devia lutar contra a tentação, apelando para todos os meios com o objetivo de fugir da Luxúria.

A Alma criada por Deus, habita um corpo corrupto, cheio de desejos carnais, libidinosos, que conduzem ao inferno. Dessa maneira o "bom-cristão", busca tudo o que é da Alma (Deus), e despreza os apelos do corpo, o amor carnal e o sexo servindo apenas para procriação. Pensamento esse nada distante, visto que muitas doutrinas religiosas ainda têm uma enorme dificuldade em conviver com o que é do corpo, aterrorizando seus seguidores com discursos moralista e dualistas, onde Alma e Corpo estão separados e convivem em um mesmo espaço com interesses diferentes como se fosse uma guerra, onde o prêmio será o Céu ou o Inferno.

Jesus Cristo, no entanto, em muito, demonstrou durante sua vida como homem, toda beleza do Corpo, sua unicidade Corpo-Espírito. Mas, a hipocrisia de alguns de seus seguidores, impediu o florescimento de um autêntico Corpo Humano, livre de culpabilizações infundadas e pecados inventados para controlar e apenas deter o poder sobre outros seres humanos.

O Pensamento Medieval a respeito do Corpo, é percebido na obra de G. Gusdorf, A agonia da nossa civilização, que assim nos relata: "Abrir o corpo de um morto para estudar sua constituição intima é um crime capital, não somente por que jamais se sabe se um morto está verdadeiramente morto, mas sobre tudo porque tal empreitada tem um caráter sacrílego. O olhar humano não deve se fixar em 
regiões que Deus nos ocultou e não deve violar uma realidade sobrenatural, um dos aspectos do destino eterno do homem" (GUSDORF, 1940 p.86). O Corpo era considerado inferior, porém criado por Deus, o que the confere um aspecto de sacralidade.

Compreende-se dessa forma o quanto causaram espanto e condenações, as experiências do médico Belga, Vesálio que viveu entre 1514-1564, quando alterou os estudos sobre a anatomia humana, que até então eram baseados em Galeno, que havia estabelecido fundamentos no século II, de como estudar e tratar o corpo. Inclusive Leonardo da Vinci, para realizar seus estudos sobre a anatomia, conseguia de forma clandestina os cadáveres que serviam de base para suas pinturas.

A transformações que ocorreram no fim do século XV e início do século XVI, provocaram uma mudança de foco. A dessacralização do corpo, considerado até então como criado por Deus, um corpo religioso, impedido de violação, passou a ser objeto de estudo da ciência secular, considerado como um objeto da natureza e da física.

Na Filosofia encontra-se René Descartes, com uma nova análise do corpo. O dualismo psicofísico cartesiano, estabelece uma relação entre a natureza espiritual e natureza material do corpo. Ele parte de uma dúvida em relação ao corpo (matéria) e ao mundo, isto é, será que o corpo e o mundo são uma realidade?

Através do cogito (pensamento), recusa a realidade do mundo e do corpo, admitindo que o corpo é pura exterioridade, material. Entende que o homem é constituído por duas realidades: a primeira realidade é a substância pensante (o pensamento) e a segunda a substância extensa (o corpo). O ser humano jamais poderá conhecer a verdade, pelo corpo, pela emoção, pelos sentidos, visto que os mesmo não são exatos, não são mensuráveis matematicamente. Ao contrário, o pensamento o cogito, por estar livre do corpo, tem a possibilidade de conhecer a realidade sem as influências imperfeitas do corpo.

Descartes, considera o corpo-objeto, máquina, diferindo da visão grega, ao afirmar: "Deus fabricou nosso corpo como máquina e quis que ele funcionasse como instrumento universal, operando sempre da mesma maneira, segundo suas próprias leis".

As consequências dessa visão de corpo se irá perceber durante todo Pensamento Moderno, inclusive com a Literatura Naturalista do século XIX, fazendo 
uma abordagem do homem como um simples joguete do meio, da raça, do momento. A educação aos poucos, estrutura-se nessa visão mecanicista, de que o corpo é uma máquina. Ideias educacionais que ainda hoje se encontram presentes dentro da sala de aula, na prática docente, nos conteúdos propostos para os alunos. Basta se analisar o quanto que se dá de importância para os aspectos subjetivos no espaço escolar.

Busca-se uma objetividade, para que os alunos não cometam "erros", como se fosse possível se encontrar uma maneira de atingir de forma objetiva o ser humano. Ingenuamente, coloca-se o aluno como se ele fosse uma máquina, sem sentimentos, sem emoções, sem subjetividades, sem afeto, como se a racionalidade respondesse objetivamente o que pode e quer o Homem.

A Arte do Século XVII, por meio das hábeis mãos do pintor Rembrandt, quando apresentou a obra, A lição de anatomia, demonstra essa visão materialista do corpo. Inclusive a palavra corpo, do latim corpus, significa cadáver, isto é, o corpo físico já não é um corpo vivente, continua sendo cadáver para Rembrandt.

As influências cartesianas se fizeram e se fazem sentir nas correntes psicológicas, que consideram apenas a exterioridade do comportamento, tais como o behaviorismo.

Não se pode deixar de lembrar que essa visão provocou muitas discussões, na busca para superar a dicotomia entre corpo e alma. O corpo-consciência teve um marco importante no século XVII, com um judeu holandês de nome Baruch Spinoza, que sentiu em sua vida as condenações por pensar diferente e tentar estabelecer uma unidade entre corpo e alma. Considerado herético, banido do judaísmo, expulso de sua família, entregou-se ao ofício de polir lentes para sobreviver e refletir.

Spinoza em sua obra, Tratado Teológico e Ética (1620), faz uma profunda crítica a toda forma de poder, seja ele político, religioso, buscando clarear quais são os obstáculos à vida. Ele se pergunta o que impede e o que facilita viver a liberdade?

Através da teoria do paralelismo, ele mostra as possibilidades de expressão da liberdade. Inova assim, os pensamentos Gregos e Cartesianos, que não abriam caminhos no campo do pensamento, de superação da dicotomia entre corpo e alma, dando ao espírito a superioridade e a função de dominar as paixões, como forma da própria humanização. 
Segundo ele, não há uma relação de superioridade entre a alma e o corpo, ou seja, uma hierarquia. A relação que se estabelece entre ambos não se dá segundo a lei da causalidade, mas de expressão e simples correspondência. O que se passa em um deles se exprime no outro: a alma e o corpo exprimem, no seu modo próprio, o mesmo evento.

Sendo assim, não se pode dizer que a alma é passiva ou o corpo ativo. Quando passivo, o homem o é de corpo e alma e quando ativo, é de corpo e alma. Se a ação tem uma causa externa, mais forte que a força interna, é se passivo, desenvolvendo a heteronímia e quando a ação tem uma origem interna, é se ativo, autônomo.

O caráter fundamental da alma consiste na atividade de pensar, de conhecer. A ignorância representa sua fraqueza. A alegria da alma consiste em produzir ideias e a tristeza está ligada à incapacidade de entender, causando um sentimento de diminuição do ser.

O encontro dos corpos pode produzir alegria ou tristeza. A alegria resulta quando a relação entre os corpos se soma, aumenta a capacidade de ação e tristeza, quando as relações entre os corpos desenvolvem uma diminuição na capacidade de ação, como, por exemplo, existe uma relação de submissão, de autoritarismo de tirania entre os corpos.

Para Spinoza (1620), a alegria e a tristeza recebem o nome de paixões e essas podem fazer sofrer, padecer. Quando as ações são determinadas por uma causa externa, não é o ser humano que age, derivando dessa forma, sentimentos de ódio, de inveja, ressentimento. Porém, quando a paixão desperta alegria, significa que está conduzindo para a autonomia, aproxima do ponto em que se tornará senhores dela.

A originalidade de Spinoza está no fato de não estabelecer uma hierarquia entre as paixões, isto é, entre as alegres e as tristes, como se uma fosse mais importante que a outra. Em sua obra Ética, escreve: "Nem o corpo pode determinar a alma a pensar, nem a alma determinar o corpo ao movimento ou ao repouso ou a qualquer outra coisa" (SPINOZA, 1620, p.81).

A liberdade não consiste em se livrar das paixões, mas em perceber que se é a causa das paixões. Para Spinoza, liberdade é autodeterminação, autonomia. Um afeto jamais é vencido por uma ideia, mas um afeto forte, autônomo, vence um afeto 
fraco, carregado de ódio e ressentimento. Somos livres, autônomos, quando explicamos que o que acontece em nós tem sua razão na própria natureza, não em causas externas.

A vida é um valor maior para este filósofo, que considera o pecado, a culpa, a falta de mérito, a moral do dever, prejudicial. Nestes termos esta linha de pensamento foi uma ilha em meio ao racionalismo dualista predominante na Filosofia Moderna. O Corpo é, não está, isto é, a unicidade entre a alma e corpo faz o Homem ser o que é, e a divisão entre corpo e alma o anula, considera-o incapaz de ser.

A visão platônico-cristã, passa a ser questionada de uma forma profunda com a Fenomenologia. O corpo não se identifica com as coisas, mas é enriquecido pela noção de que o homem é um ser-no-mundo. O Corpo é o primeiro momento da experiência humana. Eu não tenho um corpo eu sou um corpo. Quando me relaciono, estabelecendo contato com o outro, me revelo pelos gestos, atitudes, mímica, olhar; enfim, pelas manifestações corporais, pelos movimento do corpo. $\mathrm{O}$ gesto do outro não é um ato mecânico, mas são uns gestos expressivos, carregados de sentido, de significado, que nos transporta para a interioridade do sujeito, isto é, do que me rodeia.

O filósofo Luijpen, escreve em sua obra Introdução à fenomenologia existencial que:

\begin{abstract}
é o outro em pessoa que vejo tremendo de medo, que ouço a suspirar de cuidados. Sinto sua cordialidade no aperto de mãos, na meiguice de sua voz, na benevolência de seu olhar. Da mesma forma, quem me odeia, que é indiferente a meu respeito, quem se aborrece comigo, quem tem medo de mim, quem me despreza ou desconfia de mim, quem me quer consolar, seduzir ou censurar, convencer-me ou divertir-me - está presente em pessoa a mim. Seu olhar, seu gesto, sua palavra, sua atitude etc. são sempre seu olhar, gesto, palavra e atitude: ele, em pessoa, está imediatamente e diretamente presente a mim (LUIJPEN, 1890 p.91).
\end{abstract}

A exploração do Corpo, através do trabalho, no sistema capitalista, recebe inúmeras críticas e explicações. Uma visão sobre por que alguns povos têm como valor cultural o trabalho, desprezando outras possibilidades que o corpo poderia apresentar, viver ou sentir, optando por perceber o corpo apenas como uma máquina que produz, encontra-se na obra, Ética Protestante e o espírito do Capitalismo, do sociólogo Max Weber, defendendo a ideia de que a essência da ética protestante baseia-se na vida ascética. Segundo a doutrina calvinista, a 
salvação independe da vontade do homem, é Deus que nos escolhe salvar ou condenar.

Porém, de acordo com esta doutrina, os sinais aqui neste mundo de que se foi escolhido por Deus para obter a salvação aparecem: nas obras, riqueza e prosperidade econômica. Deriva daí, que Max Weber, relaciona o Capitalismo com a Reforma Protestante do final da Idade Média. O trabalho seria uma maneira de escapar da tentação, de purificar-se, e o principal pecado é a preguiça. A moral Burguesa fundamenta-se na ideia de que o trabalho desenvolve, aprimora o ser humano e a ociosidade é a mãe de todos os vícios. Ao corpo nada de prazer, apenas dever. É uma máquina que produz, gera riquezas. O prazer passa ser apenas virtual, pela televisão, comprado na banca de revistas, pois o prazer real ao que trabalha não pode ser propiciado.

O Sistema Capitalista estrutura-se em cima de uma Educação Escolar disciplinadora, perversa e indutora. Produzindo Homens submissos, aficionados pelo ter, dominar e possuir. Se descobrirem o prazer do corpo, não aceitam a dominação e exploração. O corpo, quando experimenta o prazer sem culpa, transforma os trabalhos adestrados, forçados, rotineiros e alienados em criação prazerosa, em vida que flui em cada um de seus atos. Resta-nos a pergunta - Ao Capitalismo interessa um Homem livre, corporalmente autônomo? Ou apenas considera-se como "cidadão", o "Homo Consumens"?

O trabalho no sistema capitalista, com jornadas de trabalho que ultrapassam o limite físico humano, faz com que o sexo seja freado, levando a dessexualização e deserotização do corpo.

Segundo Freud (1920, p.123), o trabalho é o resultado da sublimação da libido. Porém, nas empresas contemporâneas, a situação de dominação a que uma classe se encontra submetida em relação ao trabalho alienado, fragmentado, repetitivo e mecânico impede a presença do prazer.

Marcuse (1947, p.23) em sua obra Eros e Civilização, faz uma análise sobre o trabalho no mundo contemporâneo. Segundo ele, as exigências da nova ordem de trabalho provocam uma super-repressão, que se encontra diretamente unida ao princípio de desempenho, segundo o qual o trabalhador internaliza a necessidade de rendimento, de produtividade, preenchendo funções preestabelecidas e organizadas em um sistema cujo funcionamento se dá independente da participação consciente 
de cada um. O Ideal de produtividade da sociedade industrial se faz por meio da repressão, isto significa que a "Eficiência e repressão convergem".

A Moral burguesa está intimamente ligada com ideia de Corpo e Prazer que o Capitalismo necessita e ajuda a manter. O sexo, por exemplo, é colocado sob controle para que não desvie sua função de procriação, entendida como fundamental. Esse puritanismo esforça-se por criar a imagem do ser que nega a realidade dos próprios impulsos eróticos porque os considera aviltantes, e o libertinismo não só aceita esses impulsos como os torna a única mola de suas ações. Em ambos os casos, um porque pretende anular o sexo, outro porque o separa da totalidade da experiência humana mais global, duplamente estamos diante de deformações da sexualidade.

A sexualidade é parte integrante do ser total e não apenas a expressão do corpo biológico ou o resultado exclusivo do funcionamento glandular. Ela é a expressão do ser que deseja, que escolhe, que ama, que se comunica com o mundo e com o outro. É uma linguagem que será tanto mais humana quanto mais pessoal for.

A Sociedade Ocidental Burguesa Cristã produziu em relação ao corpo, um discurso mercantilista, laborioso, pecaminoso. E mais, quando o Corpo inicia sua trajetória, encontra um mundo dado, onde existir, é incorporar uma essência através das instituições sociais e culturais, tais como a Religião, a Educação familiar e social. Não existe um mundo a ser construído e sim, um mundo a ser absorvido.

Sartre (1960 p.74), filósofo existencialista francês nos questiona sobre essa forma de existir ao propor a seguinte ideia: "a existência precede a essência", contrariando ao pensamento Cristão em que "a essência precede a existência". Para o existencialista existir é "fazer carência-de-ser", isto é, primeiro existo, construo meu mundo, em seguida construo minha essência humana. Nessa perspectiva, a ideia de corpo também passa por uma revisão conceitual. O corpo, conforme o pensamento medieval e cristão, seria onde mora a alma, portanto existencialista o Corpo aparece como a morada do ser, como espaço de vida, onde se dá a existência, sem pré-conceito.

Para Sartre, o Corpo desprezível como ser em si, mas valorizado como morada da alma. Na concepção, é a experiência do que é "ultrapassado" e "passado". Em cada projeto para-si (isto é, da consciência), em cada percepção o 
Corpo está lá. Ele é o passado imediato, porquanto aflora ainda no presente o que Ihe foge. Isso significa que ele é, ao mesmo tempo, ponto de vista e ponto de partida: um ponto de vista, um ponto de partida que sou e que, ao mesmo tempo, ultrapassado em direção do que hei de ser.

Ao pensarmos o Corpo contemporaneamente, necessitamos mencionar o nome e o pensamento de Friedrich Nietzsche, filósofo alemão, filho de pastor luterano, órfão de pai aos 5 anos e criado em um ambiente formado por cinco mulheres. Excelente estudante e mais tarde professor. Deu o exemplo, refletindo com sua própria cabeça e com seus sentimentos, de forma original.

Nietzsche foi, ao lado de Marx e Freud, um perturbador da ordem estabelecida com a industrialização, com a chegada da burguesia definitivamente ao poder. Uma dessas pessoas que através das ideias transforma os valores e as crenças. Dentre os três, Nietzsche, foi o mais contundente crítico da pedagogia judaico-cristã que estruturou o Ocidente. As indagações que propôs ao cristianismo, sobre os valores, são inovadores no método. Sua ideia sobre fazer seguidores, ou sistemas de pensamento, estruturados assim se expressava: 'Desconfio dos fazedores de sistemas e me afasto de seu caminho. A vontade de sistema é uma falta de probidade" (NIETZSCHE, 1894, p.22).

A fórmula que Platão utilizava para entender o corpo é contrariada por Nietzsche, que propõe o Corpo como fio condutor. O Corpo é nosso guia mais seguro e efetivo para esclarecermos de forma total todas as questões filosóficas. Para ele, os sentidos, os instintos e os afetos nos proporcionam um entendimento e um mergulho na realidade. O corpo é um fenômeno mais claro, evidente que um "ser" não material, como a alma ou o espírito. Os pensamentos são gerados a partir dos instintos e das pulsões.

As consequências de colocar o corpo como fio condutor das reflexões são muitas. Primeiro, provoca a ruína da tradição idealista, que se baseia na existência do mundo inteligível e da alma imaterial. Em segundo lugar, provoca uma modificação, uma reversão na valorização do corpo e da terra. Os valores têm um fundamento corporal. Ao livrar o corpo de estigmas milenares, todas as suas partes tornam-se uma maravilha. O mundo merece ser dançado, cantado. A visão idealista o considerava inimigo da perfeição com sua ética cheia de culpa e tristeza, ao passo que a ética de Nietzsche, terrestre, é da alegria e do prazer. 
Em sua análise da civilização, Nietzsche identifica três períodos no percurso ideológico do Ocidente. "Tu deves" é o período em que há o domínio da moral e da religião, isto é, o domínio do dever. O homem tem a ilusão de estabelecer verdades definitivas. Simbolizado pelo camelo, que representa a submissão, os homens são como um rebanho, escravos, a culpa e o desprazer corporal marcam este período. "Eu quero" caracteriza-se pela decadência do mundo do dever, é o declínio dos valores supremos do período anterior. Um período de transição. Tendo como símbolo o leão, representa uma adolescência, politicamente os revolucionários que perturbam a ordem, mas nem sempre a transformam. "Eu Sou", marca a fase em que se dá uma nova relação do Corpo com sua existência. A criança tomada como símbolo representa a alegria, a espontaneidade, a vida que flui sem preconceitos, sem culpa, o desejo que é assumido, o prazer de viver.

\section{A GÊNESE DO CORPO...}

"É um movimento muito primitivo, sensações muito arcaicas, é movimento lento e contínuo da ameba".

O Corpo aparece na origem da vida. E este corpo quando surge se expressa no movimento, que é o movimento da vida ou "pulsão da vida". No útero a formação corporal aparece na formação do embrião, que é corpo.

Esse desenvolvimento biológico, a necessidade fisiológica, segundo Freud, cria o desejo psíquico, e a satisfação da necessidade do prazer. "Tudo o que é prazer do corpo, tem um conteúdo sexual difuso e primitivo ao nível do prazer de ser, de existir na mobilidade de seu corpo"(LAPIERRE, 1960 p.71).

Somos um corpo que traz toda sua carga histórica de sensações de prazer mais primitivas e profundas. Toda modulação tônica atualiza, essas sensações primeiras. Ao ocupar o espaço externo com o nascimento, esse corpo encontra o não movimento ou a imobilidade, depara-se com outros movimentos que não os seus, com conteúdos de prazer e desprazer ou proibições sociais. Desse momento em diante, o corpo vai se modelando, gerando conflitos, oriundos do desejo de existir, de ser ,desejo de ação, ser ou de não ser mais.

Talvez esteja aí, no plano filogenético, a origem primitiva da consciência nos seres vivos, da percepção (não-racionalizada). A civilização despreza essa 
dimensão em favor das percepções racionais, mas é o ressurgimento espontâneo dessas percepções que dá sua dimensão afetiva às sensações de toque e contato (sensualidade).

É a história desse corpo, de seus desejos, que em sua ação revela seus conflitos. O corpo presente na história pessoal, na história da humanidade e poderíamos dizer que na história da espécie humana desde sua origem. Toda ação humana, no trabalho, na educação, nas artes, enfim, em todos os lugares que o homem ocupa o espaço com seu corpo, deveria ter como preocupação primeira a preservação deste movimento de vida, desejo de SER

\section{PSICOMOTRICIDADE RELACIONAL E O CORPO}

Todo o meu percurso profissional gravita ao redor de uma única palavra, de um único conceito que constitui o referencial permanente de toda minha evolução - o corpo -, a atividade motora sob todos os aspectos. (LAPIERRE, 1940, p.17).

Uma grande mudança de postura ocorreu em relação ao Corpo, no século vinte. Mais precisamente após a segunda Guerra Mundial (1945).

O Corpo passou a ser tratado, visto, reconhecido como um ser de unidade, não dividido entre matéria e espírito. Analisado de forma maniqueísta como se uma de suas partes fosse melhor, de mais qualidade que outra, ou em outras palavras, sagrada e profana.

O surgimento da Psicomotricidade como ciência específica, no inicio do século XX, foi um passo importante. Mas determinante que ocorreu quando André Lapierre desenvolveu de forma pioneira, na França, a Psicomotricidade Relacional.

Em suma, a Psicomotricidade na sua essência, não é só a chave da sobrevivência, como se observa no animal e na espécie humana, mas é igualmente, a chave da criação cultural, em síntese, a primeira e última manifestação da inteligência. A Psicomotricidade, em termos filogenéticos, tem, portanto, um passado de vários milhões de anos, porém uma história restrita de apenas cem anos. A motricidade humana, a única que se pode denominar por psicomotora, é distinta da motricidade animal por duas características: é voluntária e possui novos atributos de interação com o mundo exterior (ECCLES, 1989). 
A motricidade transformou a anatomia, a fisiologia e a psicologia do ser humano, modificou as suas funções e com ela, a inteligência que a utiliza. A motricidade humana, por analogia a única susceptível de se designar por psicomotricidade, exige a tomada de consciência, uma vontade motivacional e um sistema de representações. Com ela, o ser humano inventou e fabricou com o corpo biológico, corpos artificiais, tendo adquirido por meio dela "órgãos" muito especializados que trabalham por ele com mais rendimento e disponibilidade. Para os paleontologistas a motricidade é o traço significativo e crucial da Evolução Humana (FONSECA, 1994).

Em síntese, a psicomotricidade é tributária de uma arquitetura funcional que se desenvolveu filogeneticamente e que se estrutura ontogeneticamente (FONSECA, 1989 e 1994), só possível numa dialética biopsicossocial, com a qual foi possível acrescentar à natureza uma civilização, e é possível acrescentar aos reflexos motores uma reflexão psicológica que decorre dum processo de aprendizagem dependente de uma mediatização que se opera num contexto social concreto.

Nem a motricidade nem a inteligência valem muito por si próprias, é a interação e a relação inteligível e informacional entre ambas, que dá ao movimento a função vicariada da inteligência (FONSECA, 1989), e tal é válido para o Homo Habilis quando se empenhou na fabricação de instrumentos, como para dar um golpe de cinzel de Miguel Ângelo...

Psicomotricidade, etimologicamente tem suas raízes em dois termos diferentes - psico e motricidade. Psico do grego "alma" e motricidade "ação que o corpo exibe no espaço e no tempo".

Conceitua-se Psicomotricidade como ciência, cujo objeto de estudo é o homem, através do seu corpo em movimento, nas suas relações com seus mundos, interno e externo.

No início do século $X X$, por volta de 1907, surgiu o termo PSICOMOTRICIDADE e o psiquiatra francês, Dupré formulou a noção de psicomotricidade, ressaltando a estreita identificação entre o movimento e a alma, inteligência, afetividade, isto é, um paralelo psicomotor. Sua linha de pensamento desenvolveu-se sob um ponto de vista psiquiátrico 
A Psicomotricidade teve sua grande evolução e revolução na França, no final da década de 50 com Ajuriaguerra. Foi o pioneiro da psicomotricidade na criança. Sua importância está no fato de que a psicomotricidade, se desvincula de uma abordagem orgânica, neurológica, para uma abordagem psicofisiológica, relacionando à aprendizagem e à vida psico-afetiva, vinculando afetos e emoções.

A psicomotricidade passou a compreender a personalidade por inteiro e correspondendo a uma análise geral do indivíduo traduzindo um certo modo de ser motor, caracterizando todo o seu comportamento.

Na França, André Lapierre, iniciava em 1952, sua carreira profissional como professor de Educação Física. O Trabalho fora desenvolvido no pós-guerra com a intenção de corrigir crianças que apresentassem deficiências morfológicas e posturais. Lapierre com muita sensibilidade desenvolveu mais que isso pois, possibilitou a essas crianças momentos de prazer, deixando-as plenas e maravilhadas.

André desenvolveu a Cinesioterapia, especializado nos tratamentos vertebrais, nas algias de origem lombalgias, neuralgias, cervicalgias, interessado na coluna vertebral, aumentando cada vez mais a sua visão do corpo.

Após cinco anos de atividades nessa área, encontrava-se com um grande acervo de documentos inéditos, os quais foram editados sob o titulo de "Reeducação Física", prestando assim grandes contribuições ao momento da Psicomotricidade.

Em 1974, foi criada a Psicomotricidade Relacional, pelo Professor André Lapierre que vem sendo divulgada no sentido do desenvolvimento do estudo e da prática da relação psicotônica-afetiva-social da criança com o adulto e com o mundo circundante.

O grande passo e força que recebeu, foi com a abertura da primeira Escola Trienal de Especialização em Psicomotricidade Relacional, na Itália, sob a direção cientifica do professor André Lapierre com o apoio e reconhecimento da ANUPI Associação Nacional Unificada da Psicomotricidade da Itália.

Em 1997, José Leopoldo Vieira iniciou, juntamente com Ibrahim Danyalgil Junior a supervisão do primeiro grupo de Psicomotricistas Relacionais em formação em Curitiba PR. 
“Todo meu percurso profissional gravita ao redor de uma única palavra, de um único conceito que constitui o referencial permanente de toda a minha evolução - O CORPO" (LAPIERRE, 1969, p. 22)

Esse testemunho podemos verificar no decorrer de toda vida profissional e pessoal, desenvolvendo esta maravilhosa e prazerosa teoria-prática ou vice-versa, de tornar a existência humana mais plena e prazerosa através do encontro com a criança que existe dentro de cada um de nós, através do contato com o corpo.

A integração do corpo, dentro de um processo analítico, foi formulada por Reich. Porém, André Lapierre, quando desenvolveu a Psicomotricidade Relacional não tomou Reich como referencial, mas sim Freud.

Lapierre (1969 p.89) acrescenta que "não parte de Freud, chega a Freud" e não poderia ser de outra forma, porque parte, sob influência rogeriana, não do corpo em si, mas da expressão livre do corpo, do "discurso corporal" e da análise de seus conteúdos.

O método, em muito se assemelha ao de Freud, porém, o "dizer", na técnica psicanalítica clássica, é um dizer verbal. Em análise corporal, o analisando diz espontaneamente com seu corpo.

Teoria essa tão simples e ao mesmo tempo, tão complexa. Simples na medida em que trata de algo que de uma certa maneira conhecemos - O Corpo, mas ao mesmo tempo tão complexa, justamente por que realmente conhecemos muito pouco ou quase nada de sua linguagem. O somático e o Psíquico se revelam em nós de uma forma diferenciada e particularizada. Cada Um é um em seu existir e ao mesmo tempo, é o outro ou se reflete no outro.

Tomando o Corpo como conceito referencial, André Lapierre, mergulha numa busca de conhecimentos, para justificar sua prática, perpassando as mais diversas Escolas Psicanalíticas, ciências, a antropologia ou filosofia, buscando sempre um base conceptual para uma teoria eminentemente prática.

A trajetória pessoal de André Lapierre é uma verdadeira epopéia profissional, carregada de desafios e de vitórias, que marcam toda sua vida. Uma busca contínua para entender o Corpo e sua linguagem. Ao nos depararmos com seus textos, entendemos que não deixa de ser na verdade uma autobiografia, por isso mesmo, marcadamente autêntica e humana. 
A Psicomotricidade Relacional surgiu justamente para ir além, da visão reducionista acadêmica da Educação Física, o exercício físico como algo puramente mecânico e com fins de desenvolver apenas o aspecto físico.

A grande pergunta é como podemos conhecer o Corpo? André Lapierre, entende que é através do lúdico e do prazer, isto é, uma ludicidade prazerosa. Um elemento fundamental é a espontaneidade, a total liberdade e resgate da criança que existe dentro de todos. Não existe uma programação para que possamos dizer que é desta ou daquela maneira, cada qual é um. A verbalização assume caráter secundário, a vivência caráter primordial.

A ternura, que nasce conosco, que está dentro de nós e que conhecemos nos primeiros anos de vida, vai aos poucos sendo substituída por racionalismos doentios, preconceitos, pseudovalores, por imposição da sociedade, de normas educacionais, de valores religiosos, que fazem com que esqueçamos que dentro de todos habita uma criança com ternura.

A liberdade e a autenticidade são os dois grandes benefícios imediatos que a Psicomotricidade Relacional propicia a todos aqueles que iniciam essa jornada, que não sabemos exatamente qual será o fim, apenas sabemos que a vida se tornará mais prazerosa e autêntica, só por isso já terá valido o percurso.

O ser humano tem como uma de suas mais importantes características a comunicação, através da fala, do olhar, do seu corpo. Professores e pais constantemente relatam que muitos alunos e filhos apresentam "distúrbios de aprendizagem", não conseguem aprender, tem dificuldades para se expressar, são fechadas em seu mundo. Muitas crianças que não dominam a linguagem verbal ou escrita, podem expressar, pelo corpo, seus medos, seu prazer corporal, compartilhando-os.

Na primeira infância já se deve começar a trabalhar com a criança, pois muitos dos conflitos têm sua manifestação no início da sua vida.

Utilizando materiais mediadores, busca-se de forma profilática, contatar esta comunicação através do lúdico e com prazer por meio do jogo, permitindo a criança viver a agressividade, a afetividade e a sexualidade, desculpabilizando-se e encontrando o prazer do brincar pelo brincar, para que seu desenvolvimento ocorra de forma mais harmoniosa futuramente. 
O registro das sensações que constituirão a "experiência de vida", os elementos básicos da constituição do psiquismo, desenvolve-se por volta do quarto mês de vida intra-uterina, assim que a constituição do sistema nervoso permite-Ihe o registro dos estímulos. Essas vivências ficam registradas na memória do inconsciente. Nessa fase de sensações fusionais, não existe o eu, nem o não-eu, pois a criança absorve tudo o que a rodeia. Por isso o nascimento é uma ruptura muito grande, resultando a sensação de perda. A criança precisa reencontrar esta fusão, pois é um elemento muito importante no desenvolvimento psicológico. $O$ contato físico não é suficiente, o que importa é a qualidade desse contato. As frustrações causadas por essa ruptura, prosseguem no resto da vida, quando se solicita uma relação permanente de contatos e carinhos.

Toda comunicação pode se resumir às diferentes combinações de cinco verbos: PEDIR - DAR - RECEBER - PEGAR - RECUSAR, que são os termos fundamentais na comunicação. A necessidade mais profunda da criança, como a de todo ser humano, é a de ser escutada, inclusive na intimidade dos sentimentos que para ela mesma não são conscientes.

\section{A FORMAÇÃO PESSOAL EM PSICOMOTRICIDADE RELACIONAL}

"O Corpo não é feito para informação objetiva, mas para comunicação" (LAPIERRE, 1940, p. 32).

A Psicomotricidade Relacional proporciona a todos que entram em contato com ela, uma mudança de paradigmas, de postura de vida, e principalmente, um relacionamento prazeroso com seu Corpo.

Em sua atividade profissional, o Psicomotricista Relacional não é só professor, a relação que estabelece com a criança é diferente, o contato se dá através do jogo simbólico, para que a criança possa expressar seus fantasmas e sentimentos provocados por eles. Os conteúdos que surgem nessa relação são carregados de afetos e emoção, tanto para a criança como para o profissional. Para que a atuação do Psicomotricista Relacional não projete seus fantasmas e seus desejos ele necessita de formação pessoal. E, durante esse período de formação irá vivenciar, confrontar-se com seus desejos e fantasmas, tomando consciência de quais são eles e os controlando. 
A teorização de algo que ocorre na Formação do Psicomotricista, principalmente a desculpabilização corporal, nem sempre é fácil.

\begin{abstract}
É preciso reconhecer que, frequentemente, o praticante de psicomotricidade tem muita dificuldade em justificar seu procedimento. Parece que seu cabedal de experiências como homem de campo lhe é suficiente: ele se coloca ao nível da "vivência", do "sentido", do "emocional". [...] Sua linguagem está impregnada pelo que partilha com a criança, mas é geralmente muito pobre e evasiva quando se trata de justificar, e mais ainda quando se trata de conceitualizar sua prática. A maior parte do tempo ele se apega a clichês pinçados aqui e ali, de teorias que assimilou mais ou menos e que só conhece de maneira parcial (AUCOUTURIER, DARRAULT; EMPINET, 1986, p.59).
\end{abstract}

Essa experiência, o autor deste escrito e outras pessoas vivenciaram e ainda vivenciam em suas vidas pessoais e no contato com o corpo do outro. Através do curso de Especialização em Psicomotricidade Relacional, oferecido pelo CIAR (Centro Internacional de Análise Relacional), entra-se em contato com o outro. Deixar-se penetrar pelo desejo do outro e penetrar no desejo do outro.

Pensa-se que isso ocorre tanto na Formação Pessoal e nos estágios posteriores com crianças, e mais tarde na vida profissional. Identificar seu desejo é uma das etapas fundamentais dessa formação. Pois, ocorre muitas vezes que nos protegemos para não sermos desejados, negando o desejo. Por trás dessa negação do desejo, o sentimento de culpa incutido em nós ao longo da vida, impede de desejarmos. Isso por que o desejo está ligado ao prazer e esse é carregado de sentimentos de culpa, como se fosse pecado e o sentimento de culpa impede assumirmos nosso desejo. Impossibilita dizermos sim à vida pois, um corpo carregado de culpa despreza a vida.

Em muitos aspectos a vida se transforma, quando se inicia o processo de formação em Psicomotricidade Relacional, não como se fosse um toque de mágica, mas sim, como fruto de uma busca profunda de tudo aquilo que se é, que já se foi, e talvez do que fizeram de cada um de nós. A criança que existe dentro de cada um de nós começa a ser despertada, e o que poderia parecer um retrocesso no senso comum, é na verdade o verdadeiro Homem que aparece.

Olhar no espelho causa receios, fugimos. Um corpo marcado por culpabilizações em sua história, em que o desejo é negado, e muitas vezes, não é permitido sequer admitir que se deseja, cega. Porém, quando paramos de fugir, as proteções, como a racionalidade, a agressividade, que servem para esconder o 
desejo de afeto vão desaparecendo. Poder emocionar-se sem culpa, identificar as projeções que fazemos na vida pessoal e profissional, os nossos fantasmas, permite vencê-los. Dizer o que sente, o que deseja, saber dizer não, e também dizer sim, viver a emoção, sem culpa em relação ao corpo, sempre tão ressaltada pela educação familiar e religiosa. Tudo isso leva-nos a uma vida mais ética. $E$ isto a Psicomotricidade Relacional proporciona.

A Agressividade, dificilmente vista como positiva, devido ao autoritarismo, é uma expressão de vida, pulsão de vida. O corpo sem agressividade é anulado, a vida sexual não aparece. A identificação com o masculino, que na maioria das vezes, é problemática na infância na formação do Psicomotricista Relacional, tornase possível. Pois, para o Homem, masculino está associado com um desempenho genital em relação à mulher objeto. No entanto, a masculinidade se forma e fortalece no encontro com o semelhante, outro masculino. E isto se dá no brincar, vivendo sem culpa as relações, os fantasmas desaparecem depois que experimentamos viver.

A agressividade é o resultado de um conflito entre o desejo de afirmação pela ação e os obstáculos e interdições que essa afirmação encontra. Ela é uma maneira de se relacionar com o outro, uma comunicação. É provavelmente o mais primitivo e espontâneo modo de comunicação face ao outro, quando ele é desconhecido.

Proibir a agressão ou reprimi-la por meios coercitivos, é entrar no jogo sadomasoquista e assim reforçá-lo.

É através do domínio da agressividade que começa a adaptação ao outro. O enfrentamento torna-se prazer comum, base de um acordo recíproco, prelúdio frequente de um acordo mais profundo que é descoberta da harmonia.

Toda criação é um ato agressivo porque escapa à norma, mas também um refúgio contra a angústia de morte. O criador só se interessa pela sua obra na medida em que a vê no presente e a projeta no futuro. Quando se torna um passado, ela só pode se desinteressar dela se quer reencontrar sua criatividade.

A sexualidade, a afetividade, a agressividade, estão entre os pontos mais importantes da existência humana. A sexualidade vista como uma dimensão fundamental do ser humano, de expressão dos sentimentos sem culpa, em que os sentimentos falam através do corpo em seu movimento em relação com o outro, com o mundo e consigo mesmo. A afetividade, em suas dimensões de contenção, de 
toque, de se doar e aceitar a doação do outro. A agressividade, não como defesa, mas como relação, como penetração no mundo, como afirmação da dimensão de homem, da masculinidade.

Há outras questões em que aparece a rejeição. Ë algo que se necessita trabalhar na formação ao se aceitar como falível, não conseguir tudo, nem se precisa conseguir tudo e sair da onipotência. Permitir-se, perder sem culpa, viver o prazer sem culpa.

A relação com o Corpo vem por demais marcada por uma profunda condenação, culpa. Libertar-se corporalmente, pressupõe destituir-se desse corpo passado, tomar consciência dessas cicatrizes ou feridas e curá-las.

O Psicomotricista Relacional, em seu trabalho profissional proporciona, por exemplo, para as crianças, a oportunidade de brincar livremente com o corpo do adulto, sendo que não existe lugar nenhum do mundo em que isso seja possível. Em segundo lugar, pensa-se que cada uma cresce em sua relação pessoal, vivendo momentos de afetividade, de fusionalidade, de agressividade e de disputas com o adulto. O Curso de Especialização em Psicomotricidade Relacional, tem sua gênese no Brasil recentemente, sendo que apresenta como diferencial, a Formação Pessoal, isto é, além de proporcionar uma qualificação profissional, desenvolve conjuntamente a Formação Pessoal. Busca dessa maneira suprimir aquela tradicional dicotomia entre teoria e prática, onde uma teoria aprendida não necessariamente leva a uma prática coerente.

O CIAR como instituição, em muito contribui para a realização desses fatos na vida dos profissionais que por ele são formados. Proporciona a cada um entender que existe um grande potencial dentro de si a ser percebido.

\section{CONSIDERAÇOES FINAIS}

O medo é ambíguo. Conforme o caso ele pode ser salutar ou destrutivo. Ele é "criador de ser" e "acedemos ao mundo pelo domínio do medo". A noção de pecado, ela própria, é geradora de um medo de si mesmo que pode ser fecundo. A culpabilidade, vivida positivamente, cria uma tensão que alivia, pode desenvolver a responsabilidade, abrir um tesouro de riquezas ocultas no fundo das pessoas. 
Mas - vertente negativa - um medo forte demais e uma linguagem de culpabilização por demais insistente podem paralisar, desencorajar, desagregar. Ao longo da história da humanidade, o corpo foi interpretado mais negativamente. A sexualidade depreciada e a insistência pesada sobre as misérias e as doenças marcavam uma forte predileção pelo macabro e declarava o espírito humano incapaz de qualquer saber autêntico.

A Psicomotricidade Relacional busca uma relação com o Corpo sem culpa, sem medo e sem condenação. O corpo está na ordem do dia, na sociedade moderna. Compra-se, vende-se e se mata o Corpo. No entanto, ao se referir ao Corpo, ou à ideia de corpo, certamente o Conceito vai além de umas noções puramente biológica, física, comercial, como se corpo e espírito fossem separados ou antagônicos. Não se tem um Corpo, é se um Corpo.

\section{REFERÊNCIAS}

ABBAGNANO, Nicola. Dicionário de Filosofia, São Paulo. Mestre Jou, 1962.

ARANHA, Maria Lúcia de A.; MARTINS, Maria Helena P. Filosofando: introdução à Filosofia. 2.ed. São Paulo: Moderna, 1993.

FONSECA, V. da. Desenvolvimento humano: da Filogênese à Ontogénese da Motricidade Humana. Lisboa: Notícias, 1989.

FREIRE, Izabel Ribeiro. Raízes da psicologia. Petrópolis, RJ: Vozes, 1997.

FREUD, Sigmund. Três ensaios sobre a sexualidade. Psicopatologia da vida cotidiana. Obras Completas, Ed. Standard Brasileira. Rio de Janeiro: Imago, 1969.

FROMM, Erich. Psicanálise da sociedade contemporânea. 6 ed. Rio de Janeiro, 1970.

LAPIERRE, André e Anne. $\mathbf{O}$ adulto diante da criança de $\mathbf{0}$ a $\mathbf{3}$ anos. Curitiba: UFPR/ CIAR, 2002.

LAPIERRE, André. Da Psicomotricidade Relacional à análise corporal da relação. Curitiba: UFPR /CIAR, 2002. 247p.

LAPIERRE, André; AUCOUTURIER, Bernard. Fantasmas corporais e prática Psicomotora. São Paulo. Manole, 1984.

A simbologia do movimento: psicomotricidade e educação. Porto Alegre: Artes Médicas, 1986. 
LINS, Daniel; GADELHA, Sylvio. Nietzsche e Deleuze: que pode o Corpo.

Organizadores. Rio de Janeiro: Relume Dumará; Fortaleza, CE: Secretaria da Cultura e desporto, 2002.

MONDIN, Batista. Curso de Filosofia. São Paulo. Paulinas, 1983. 3 v. 